КОНСТИТУЦІЙНЕ ПРАВО; МУНІЦИПАЛЬНЕ ПРАВО

УДК 342.7

DOI https://doi.org/10.32844/2618-1258.2019.5-2.4

МИТНИк О.В.

\title{
ГАРАНТІЇ В МЕХАНІЗМІ ЗАХИСТУ КОНСТИТУЦІЙНИХ ПРАВ І СВОБОД ЛЮДИНИ
}

Держава не лише проголошує пріоритетність прав людини і закріплює їх зміст на рівні Конституції, але і має позитивне зобов'язання створити найкращі умови для реалізації цього права. Інакше кажучи, на державу покладено обов'язок забезпечити систему гарантій прав і свобод людини. Водночас поняття гарантій не можна розглядати окремо, безвідносно до системи забезпечення і захисту прав людини, Навпаки, гарантії прав людини дозволяють ефективно функціонувати механізмам реалізації та захисту прав і свобод.

У статті здійснено аналіз сутності, функцій гарантій конституційних прав i свобод у взаємозв'язку з механізмом захисту конституційних прав, а також досліджено види гарантій залежно від функцій, які вони виконують. Визначено гарантії механізму захисту конституційних прав і свобод людини як систему відповідних засобів, способів, за допомогою яких створюються умови для належного та ефективного функціонування механізму захисту конституційних прав і свобод людини. Наголошено, що однією з ключових ознак гарантій механізму захисту прав людини $\epsilon$ їх системність, водночас у науці конституційного права не вироблено єдиного підходу щодо виокремлення складників такої системи.

Автор розглядає систему гарантій механізму захисту конституційних прав i свобод людини як сукупність взаємоузгоджених нормативно-правових та інституційних гарантій, які перебувають у тісній взаємодії та взаємозв'язку. Нормативно-правові гарантії визначено як відповідні положення, які містяться у нормах конституційного права та передбачають правові основи для функціонування конституційно-правового механізму захисту прав і свобод людини. В свою чергу інституційні гарантії механізму захисту конституційних прав людини автор пропонує розглядати як систему відповідних інституцій - органів державної влади, місцевого самоврядування, інститутів громадянського суспільства, діяльність яких спрямована на захист прав і свобод людини і громадянина в Україні.

Ключові слова: гарантії прав людини, захист прав, механізм захисту, нормативні гарантії, інституційні гарантії, конститущійні права.

The state not only proclaims the priority of human rights and consolidates their content at the level of the Constitution, but also has a positive obligation to create the best conditions for the exercise of this right. In other words, the state has a duty to provide a system of guarantees of human rights and freedoms. At the same time, the notion of guarantees cannot be considered separately, irrespective of the system of protection and protection of human rights. On the contrary, guarantees of human rights allow effective functioning of mechanisms of realization and protection of rights and freedoms.

The article analyzes the nature, functions of guarantees of constitutional rights and freedoms in relation to the mechanism for protection of constitutional rights, the types of guarantees, depending on functions implemented are examined as well. The author considers the guarantees of the mechanism for the protection of constitutional rights and freedoms as a system of appropriate means, ways by which the conditions for the proper and effective functioning of the mechanism for the protection of constitutional rights and freedoms are created.

(C) МИТНИК О.В. - аспірантка кафедри конституційного права юридичного факультету (Київський національний університет імені Тараса Шевченка) 
It is emphasized that one of the key features of the guarantees of the human rights protection mechanism is their systematic nature. At the same time, the science of constitutional law did not develop a single approach to the separation of constituent elements of such a system. In author's view, such a system of guarantees for the mechanism for the protection of constitutional rights and freedoms should be seen as a set of mutually agreed regulatory and institutional safeguards that are closely interconnected.

Legal guarantees should be defined as relevant provisions contained in the rules of constitutional law that provide the legal basis for the functioning of the constitutional and legal mechanism for the protection of human rights and freedoms. The author defines institutional guarantees of the mechanism for the protection of constitutional rights as a system of relevant institutions - state bodies, local self-government, civil society institutions whose activities are aimed at protecting the rights and freedoms of human and citizen in Ukraine.

Key words: human rights guarantees, protection of rights, mechanism for protection, regulatory guarantees, institutional guarantees, constitutional rights.

Вступ. Преамбула до Загальної декларації прав людини закріпила зобов'язання держав сприяти загальній повазі і дотриманню прав людини і основних свобод. Норми, викладені у цьому засадничому міжнародному документі, проголошуються як завдання, до виконання якого повинні прагнути всі народи і всі держави з тим, щоб кожна людина і кожний орган суспільства, завжди маючи на увазі декларацію, прагнули шляхом освіти сприяти поважанню прав і свобод i забезпеченню шляхом національних і міжнародних прогресивних заходів загального й ефективного визнання і здійснення їх як серед народів держав-членів організації, так і серед народів територій, які перебувають під їх юрисдикцією [8].

Ідея щодо обов'язку держави утверджувати і захищати права кожного, хто знаходиться під iї юрисдикцією, знайшла відображення і у положеннях Конституції України. Так, частина друга статті 3 Конституції України наголошує, що права і свободи людини та їх гарантії визначають зміст і спрямованість діяльності держави. Держава відповідає перед людиною за свою діяльність. Утвердження і забезпечення прав і свобод людини $є$ головним обов'язком держави. Формулювання частини другої статті 22 Конституції продовжують зміст згаданої статті Конституції та засвідчують, що права і свободи людини і громадянина, закріплені цією Конституцією, не $\epsilon$ вичерпними. Конституційні права і свободи гарантуються і не можуть бути скасованими [10].

Тлумачення цієї норми міститься у рішенні Конституційного Суду України у справі за конституційним поданням 51 народного депутата України щодо відповідності Конституції України (конституційності) положень статей 24, 58, 59, 60, 93, 190-1 Кримінального кодексу України в частині, що передбачає смертну кару як вид покарання (справа про смертну кару) від 29 грудня 1999 року № 11-рп/1999: «За своїм змістом положення частини другої статті 22 Конституції України передбачають обов'язок держави гарантувати конституційні права і свободи, насамперед право людини на життя, та утримуватися від прийняття будь-яких актів, які призводили б до скасування конституційних прав і свобод, а отже і права людини на життя (абзаци другий, третій пункту 3 мотивувальної частини рішення) [14]. Таким чином держава не лише проголошує пріоритетність прав людини і закріплює їх зміст на рівні Конституції, але і має позитивне зобов'язання створити найкращі умови для реалізації цього права. Інакше кажучи, на державу покладено обов'язок забезпечити систему гарантій прав і свобод людини.

Водночас поняття гарантій не можна розглядати окремо, безвідносно до системи забезпечення і захисту прав людини. Навпаки, гарантії прав людини дозволяють ефективно функціонувати механізмам реалізації та захисту прав і свобод.

Постановка завдання. Метою статті є здійснення аналізу сутності, функцій гарантій конституційних прав і свобод у взаємозв'язку з механізмом захисту конституційних прав, а також дослідження видів гарантій залежно від функцій, які вони виконують. Крім того, автор ставить за мету пошук шляхів для більш ефективного функціонування механізму захисту конституційних прав і свобод завдяки удосконаленню системи гарантій конституційних прав і свобод.

Результати дослідження. Як свідчить міжнародний досвід, ефективність гарантій основних прав і свобод людини і громадянина залежить від рівня розвитку правових інститутів демократії, стану економіки, правотворчої діяльності в суспільстві, рівня правового виховання і культури населення, належного функціонування державної влади. Таким чином гарантії прав і свобод людини і громадянина, їх широта, реальність здійснення виражають не тільки фактичний 
та юридичний статус особи в суспільстві, а й суть діючої в країні демократії, соціальні можливості, закладені в суспільному ладі. Вони є показниками зрілості суспільства, його досягнень, тим більше, що саме на державу та її органи Конституція і закони України покладають обов’язок забезпечення прав і свобод людини і громадянина [6, с. 30].

У цьому контексті варто погодитися із О.О. Чубом, який зазначає, що для практичної реалізації будь-якого суб'єктивного права важливо не тільки записати й урочисто проголосити норму про відповідне право в Конституції, але й докласти зусиль для того, щоб люди ії засвоїли, щоб iii виконання підкріплювалося системою реальних конституційно-правових гарантій [22, с. 92].

Слово «гарантія» у перекладі з французького означає «поруку», «забезпечення» [18, с. 29]. Це соціальне явище, яке забезпечує досягнення конкретного результату, створює умови для функціонування певних суспільних відносин [17, с. 130]. О.Ф. Скакун під гарантіями прав, свобод та обов'язків людини та громадянина розуміє систему соціально-економічних, політичних, юридичних умов, способів і засобів, які забезпечують їхню фактичну реалізацію, охорону та надійний захист [16, с. 203]. Подібного підходу дотримуються й Л.П. Гарчева і О.Н. Ярмиш, які зазначають, що гарантії основних прав і свобод громадян $є$ системою норм, принципів, умов і вимог, які забезпечують дотримання прав, свобод і законних інтересів громадян [5, с. 128].

На думку С.С. Алексєєва, гарантіями є умови й особливі юридичні механізми, покликані забезпечити фактичну реалізацію законоположень [1, с. 135]. Гарантії $є$ низкою конкретних засобів, завдяки яким стає реальним ефективне здійснення громадянами їхніх прав і свобод, їх охорона та захист від правопорушення. Головне призначення гарантій полягає у забезпеченні всіх і кожного рівними правовими можливостями для набуття, реалізації, охорони та захисту суб'єктивних прав і свобод. Роль і значення гарантій прав і свобод особи визначається тим, що вони $\epsilon$ важливими чинниками в економічній, політико-правовій, культурній та інших сферах життя суспільства, які створюють умови для реальної можливості здійснення прав і свобод особи [2, с. 27].

На думку І.Й. Магновського, гарантіям прав і свобод людини притаманна низка ознак: нормативність, доцільність, формальна визначеність, які є втіленням справедливості, системність, фундаментальність, безперервність дії, значущість, забезпеченість державою, універсальність, пріоритетність, індивідуальність дії [11, с. 11]. Системність як одна з ключових ознак гарантій прав людини полягає в тому, що всі вони перебувають у тісній взаємодії між собою та $\epsilon$ взаємопов'язаними і взаємоузгодженими, утворюючи таким чином цілісну систему. 3 огляду на це у науці конституційного права існують різні класифікації гарантій прав і свобод людини та громадянина.

Так, Ю.С. Шемшученко розрізняє чотири види гарантій: економічні, політичні, ідеологічні й юридичні. У свою чергу юридичні гарантії - це правові норми та інститути, які забезпечують можливість безперешкодного здійснення прав особи, їх охорону, а в разі протиправних посягань - захист і поновлення [23, с. 555]. I юридичні, і загальні гарантії знаходяться у нерозривній єдності.

В.Ф. Погорілко поділяє гарантії прав і свобод людини на дві основні групи: загальносуспільні (загальносоціальні) та юридичні. У складі загальносуспільних гарантій науковець виокремлює політичні, економічні, соціальні та духовні (культурні) гарантії, тобто відповідно до суспільних систем - політичної, економічної, соціальної, культурної (духовної), які склалися й функціонують у суспільстві [12, с. 41].

П.М. Рабінович пропонує класифікувати гарантії прав і свобод людини на загальносоціальні та спеціальні. До загальносоціальних належать економічні, політичні, духовно-ідеологічні. Спеціальні - це встановлені державою юридичні норми, спрямовані на забезпечення прав людини, а також практична діяльність із застосування цих норм і правозастосовчі акти відповідних органів влади [13, с. 7-8]. На думку К.Г. Волинки, у системі гарантій прав людини слід розрізняти загальні та правові гарантії, при цьому юридичні гарантії прав і свобод особи поділяються на нормативно-правові та інституційно-організаційні [4, с. 8-9].

Слід зауважити, що у науці конституційного права існують й інші підходи до класифікації гарантій прав і свобод людини та громадянина. Не вдаючись до дискусій щодо сутності інших видів гарантій прав і свобод людини, автор розглядає саме правові (юридичні) гарантії прав людини, які безпосередньо стосуються предмета цього дослідження. Юридичні гарантії прав і свобод людини та громадянина у наукових джерелах розглядаються як правові норми та інститути, які забезпечують можливість безперешкодного здійснення прав особи, їх охорону, а в разі протиправних посягань - захист і поновлення юридичної гарантії, встановленої Конституцією та іншими законами України [23, с. 555]. 
О.Ф. Фрицький зазначає, що правові гарантії - це надання державою формальної (юридичної) загальнообов’язковості умовам, необхідним для того, щоб кожна людина могла скористатися особистими правами і свободами [20, с. 177]. На думку I.Й. Магновського, юридичні гарантії прав і свобод - це сукупність умов та спеціальних правових способів і засобів, за допомогою яких забезпечується безперешкодне їх здійснення, охорона та захист [11, с. 16]. Є.В. Білозьоров у свою чергу зауважує, що поняття правових гарантій прав людини як система умов, засобів i способів забезпечення можливостей для реалізації цих прав зазвичай вживають для визначення гарантій у широкому розумінні цього терміну. Щодо правових гарантій, то потрібно зазначити, що ці правові умови, засоби та способи визначають процедуру реалізації прав і свобод людини та громадянина у спосіб та формі, закріплених національним законодавством держави й актами міжнародного права [2, с. 28].

T.М. Заворотченко визначає конституційно-правові гарантії прав і свобод людини і громадянина в Україні як передбачену Конституцією і законами України систему правових норм, організаційних засобів і способів, умов і вимог, за допомогою яких здійснюється охорона і захист прав, свобод та законних інтересів людини і громадянина [7, с.7].

Для гарантування можливості користуватися всіма правами та свободами людини і громадянина держава повинна забезпечити реалізацію конституційних прав і свобод, створити відповідний механізм їх гарантування [15, с. 3]. У науці конституційного права виокремлюється три рівні механізму гарантування прав і свобод: перший - гарантії, записані в Конституції, які свідчать про значущість тих умов і засобів, за допомогою яких забезпечуються права і свободи; другий - гарантії, передбачені поточним законодавством (прийняті на базі Конституції). При цьому кожна галузь законодавства має різну питому вагу в гарантуванні прав і свобод; третій - гарантії, які містяться у прийнятих на основі Конституції і законів численних актах державного управління [11, с. 16-17].

На думку деяких науковців механізм юридичних гарантій конституційних прав і свобод людини і громадянина можна розглядати в статиці та динаміці. Зокрема, в статиці - як сукупність юридичних умов реалізації та засобів захисту цих прав, що втілюється в правовій поведінці суб'єктів зазначених прав із метою перетворення їх у життя. 3 точки зору динаміки цього явища це регламентований процес забезпечення реалізації та захисту конституційних прав і свобод як конкретних юридичних можливостей, який передбачає наявність певних стадій:

1) позитивне закріплення конституційних прав і свобод, що відповідають міжнародним актам про права людини;

2) створення системи правових інститутів, уповноважених правом на використання юридичних засобів;

3) юридична (організаційно і процесуально оформлена) діяльність інститутів і громадян;

4) формування у громадян правових навичок і культури прав людини.

Функціонування вказаного механізму передбачає взаємодію його складників як по вертикалі, так і по горизонталі [21, с. 21].

Слід зазначити, що конституційно-правовою наукою не вироблено єдиної позиції щодо виокремлення видів юридичних (правових гарантій) прав і свобод людини. На думку I.Й. Магновського, такі гарантії можна умовно поділити на три групи: 1) гарантії реалізації; 2) гарантії охорони; 3 ) гарантії захисту.

До першої групи належать межі прав і свобод, їх конкретизація у законодавстві; конституційно-правові принципи статусу особи; юридичні факти, з якими пов’язується володіння ними та безпосереднє користування; процесуальні форми реалізації; заходи заохочення та стимулювання правомірної поведінки; юридичні обов'язки.

До складу другої входять взаємопов'язані заходи, спрямовані на запобігання правопорушень, встановлення та знешкодження умов і причин, які їх породжують. Третю групу утворюють норми, які представляють юридичні засоби для безпосереднього захисту вже порушених прав i свобод, які визначають порядок використання цих засобів, а також порядок поновлення таких прав і порядок застосування санкцій до винних у їх порушеннях. Отже, охорона включає заходи, які застосовуються до моменту порушення прав людини, а захист - після вчинення правопорушення або у тому випадку, коли при їх здійсненні створюються певні перешкоди [11, с. 16].

Іншої позиції дотримується М.В. Вітрук, який поділяє правові гарантії на дві групи: 1) гарантії реалізації прав і свобод; 2) гарантії охорони прав і свобод [3, с. 31]. Дещо іншу точку зору висловлює К.Б. Толкачов, який вважає, що правові гарантії поділяються на гарантії реалізації і гарантії охорони (захисту). Реалізація прав і свобод, як зазначає науковець, є не можливою без їх- 
ньої охорони, бо немає такого права, яке не потребує охорони. Гарантії охорони, які є структурними елементами механізму забезпечення прав і свобод, $є$ водночас гарантіями їхнього здійснення, тобто не можуть існувати за межами реалізації прав і свобод [19, с. 108].

Автор вказує на необхідність розмежування правових гарантій охорони та захисту прав людини, оскільки засоби охорони діють до порушення прав особи, в той час як засоби захисту «включаються» у цей механізм вже після порушення відповідних прав особи. У роботах деяких науковців запропоновано виокремлювати нормативно-правові та інституційно-організаційні гарантії захисту прав людини. Так, нормативно-правові гарантії містяться в нормах матеріального та процесуального права як юридичні засоби захисту прав і свобод; інституційно-організаційні у нормативно-правових актах, що стосуються суспільно-політичних інституцій, в яких регламентується діяльність державних і суспільних інституцій, що здійснюють захист прав і свобод [11, c. 16-17].

В.В. Книш також пропонує виокремлювати дві основні групи гарантій, спрямованих на захист прав людини: правові (нормативні) гарантії, які передбачають юридичне закріплення прав людини та визначають механізми їх гарантування; організаційні (інституційно-функціональні) гарантії, що передбачають сукупність державних і громадських організацій у сфері забезпечення та захисту прав людини [9, с. 122].

Слід зауважити, що кожна галузь права має власні механізми гарантування прав людини, у зв'язку з чим розмежовують цивільно-правові, адміністративно-правові гарантії. Водночас цікавим із точки зору досягнення мети цього дослідження $є$ аналіз саме гарантій конституційно-правового механізму захисту прав і свобод людини, які варто визначити як систему відповідних засобів, способів, за допомогою яких створюються умови для належного та ефективного функціонування конституційно-правового механізму захисту прав і свобод людини. Таку систему слід розглядати як сукупність взаємоузгоджених нормативно-правових та інституційних гарантій, які перебувають у тісній взаємодії та взаємозв'язку.

Нормативно-правові гарантії можна визначити як відповідні положення, що містяться у нормах конституційного права та передбачають правові основи для функціонування конституційно-правового механізму захисту прав і свобод людини. У свою чергу інституційні гарантії конституційно-правового механізму захисту прав людини доцільно розглядати як систему відповідних інституцій - органів державної влади, місцевого самоврядування, інститутів громадянського суспільства, діяльність яких спрямована на захист прав і свобод людини і громадянина в Україні.

Висновки. Гарантії механізму захисту конституційних прав і свобод людини можна визначити як систему відповідних засобів, способів, за допомогою яких створюються умови для належного та ефективного функціонування механізму захисту конституційних прав і свобод людини. Однією з ключових ознак гарантій механізму захисту прав людини є їх системність. Водночас у науці конституційного права не вироблено єдиного підходу щодо виокремлення складників такої системи.

На думку автора, таку систему гарантій механізму захисту конституційних прав і свобод людини слід розглядати як сукупність взаємоузгоджених нормативно-правових та інституційних гарантій, які перебувають у тісній взаємодії та взаємозв'язку. Нормативно-правові гарантії можна визначити як відповідні положення, які містяться у нормах конституційного права та передбачають правові основи для функціонування конституційно-правового механізму захисту прав і свобод людини. У свою чергу інституційні гарантії механізму захисту конституційних прав людини доцільно розглядати як систему відповідних інституцій - органів державної влади, місцевого самоврядування, інститутів громадянського суспільства, діяльність яких спрямована на захист прав і свобод людини і громадянина в Україні.

\section{Список використаних джерел:}

1 АлексеевС.С.Правоиперестройка:вопросы,раздумья,прогнозы.М.:Юрид.лит, $1983.234 \mathrm{c}$.

2. Білозьоров С.В. Правові гарантії захисту прав і свобод людини в Україні: реалії та проблеми / Є.В. Білозьоров // Адвокат. 2009. № 8. С. 26-30.

3. Витрук Н.В. О юридических средствах обеспечения реализации и охраны прав советских граждан / Н.В. Витрук // Изв. вузов. Правоведение. 1964. № 4. С. $29-38$.

4. Волинка К.Г. Механізм забезпечення прав і свобод особи: питання теорії і практики : автореф. дис. канд. юрид. наук: 12.00.01 / Ін-т держави і права ім. В.М. Корецького. К., 2000. 16 с.

5. Гарчева Л.П., Ярмыш А.Н. Конституционное право Украины : учебное пособие. Симферополь : ДОЛЯ, 2000. 336 с. 
6. Дорошева Е.Н., Одегова Т.И. Конституционные гарантии прав и свобод человека и гражданина в Украине / Е.Н. Дорошева, Т.И. Одегова // Правничий часопис Донецького університету. 2011. № 1 (25). С. 30-35.

7. Заворотченко Т.М. Конституційно-правові гарантії прав і свобод людини і громадянина в Україні : [монографія] / Т.М. Заворотченко. Дніпропетровськ : Вид-во Дніпропетров. нац. ун-ту, 2007. $256 \mathrm{c}$.

8. Загальна декларація прав людини // Офіційний вісник України від 15.12.2008, № 93, c. 89 , ст. 3103 .

9. Книш В.В. Порівняльно-правовий аналіз конституційних механізмів захисту прав людини в Україні та Польщі / В.В. Книш // Науково-інформаційний вісник «Право». № 9. 2014. C. $121-128$.

10. Конституція України від 28.06.1996, № 254к/96-ВР // Відомості Верховної Ради України від 23.07.1996-1996. № 30, стаття 141.

11. Магновський І.Й. Гарантії прав і свобод людини та громадянина в праві України (теоретико-правовий аспект) : автореф. дис. канд. юрид. наук: 12.00.01 / Ігор Йосифович Магновський. Київ : Б.в., 2003. 20 с.

12. Нова Конституція України: Огляд, коментарі і текст Основного Закону / За ред. В.Ф. Погорілка. К. : Правова держава, 1997. 156 с.

13. Рабінович П.М. Права людини і громадянина у Конституції України (до інтерпретації вихідних конституційних положень). Харків : Право, 1997. 64 с.

14. Рішення Конституційного Суду України у справі за конституційним поданням 51 народного депутата України щодо відповідності Конституції України (конституційності) положень статей 24, 58, 59, 60, 93, 190-1 Кримінального кодексу України в частині, що передбачає смертну кару як вид покарання (справа про смертну кару) від 29 грудня 1999 року № 11-рп/1999 // Офіційний вісник України від 11.02.2000, № 4, с. 114, ст. 126.

15. Савенко М. Забезпечення прав і свобод людини і громадянина та їх захист органами конституційної юрисдикції / М. Савенко // Право України. 1999. № 2. С. 3-9.

16. Скакун О.Ф. Теория государства и права : [учебник] / О.Ф. Скакун. Х. : Консум; Ун-т внутр. дел, 2000. 704 с.

17. Словник іншомовних слів / уклад.: С.М. Морозов, Л.М. Шкарапута. К. : Наукова думка, 2000. с. 130.

18. Словник української мови: в 11 т. / АН УРСР. Інститут мовознавства; за ред. І.К. Білодіда. К. : Наукова думка, 1970-1980. Том 2, 1971. с. 29.

19. Толкачев К.Б. Методологические и правовые основания личных и конституционных прав и свобод человека и гражданина и участие в их защите органов внутренних дел : монография. Спб., 1997. 175 с.

20. Фрицький О.Ф. Конституційнеправо України : підручник. К. :Юрінком Інтер, 2003.536с.

21. Хазов Е.Г. Конституционные гарантии прав и свобод человека и гражданина в России: теоретические основы и проблемы реализации : автореф. дис. на соиск. учен. степени д-ра юрид. наук: спец. 12.00.02 «Конституционное право; муниципальное право» / Е.Г. Хазов. Моск. ун-т МВД России. Москва, 2011. 24 с.

22. Чуб О.О. Конституційне право громадян України на участь в управлінні державними справами : [монографія] / О.О. Чуб. Х. : Одіссей, 2005. 232 с.

23. Юридична енциклопедія: В 6 т. / Редкол.: Ю.С. Шемшученко та ін. К. : «Укр. Енциклопедія», 1998. Т. 1: А-Г. 672 с. 